\title{
Multivariate relationship among body protein, fat, and macrominerals of male and female Saanen goats using canonical correlation analysis
}

\author{
Julián Andrés Castillo Vargas ${ }^{1}$ iD, Amélia Katiane Almeida ${ }^{1}$ (iD, Carla Joice Härter ${ }^{1}$ (iD, \\ Anaiane Pereira Souza ${ }^{1}$ iD, Márcia Helena Machado da Rocha Fernandes ${ }^{1}$ (D), Kléber Tomás \\ de Resende ${ }^{1}$, Izabelle Auxiliadora Molina de Almeida Teixeira ${ }^{1^{*}}$ (iD)
}

${ }^{1}$ Universidade Estadual Paulista, Departamento de Zootecnia, Jaboticabal, SP, Brasil.

\begin{abstract}
The objective of this study was to investigate the multivariate relationship among body protein, fat, and macrominerals in Saanen goats of different sexes (castrated males, females, and intact males) using canonical correlation analysis. Individual records of 274 Saanen goats combined from 10 studies was used. Two sets of body constituents were established: the first one contained variables related to body protein or fat (canonical variate $U$ ) and the second contained variables related to body calcium, phosphorus, magnesium, sodium, or potassium (canonical variate $\mathrm{V}$ ). Two canonical pairs were identified for each sex. However, irrespective of sex, first canonical pairs accounted for more than $87 \%$ of variance of the dependent variables, these only being used for the analysis. For canonical variate $\mathrm{U}_{1}$, canonical weights for protein were greater than that for fat (in castrated males, protein $=0.62$ and fat $=0.41$; in females, protein $=0.96$ and fat $=0.039$; and in intact males, protein $=0.81$ and fat $=0.20$ ) For canonical variate $\mathrm{V}_{1}$, in males, the highest canonical weights were for potassium and phosphorus, whereas the lowest were for calcium (in castrated males, potassium $=0.485>$ phosphorus $=0.259>$ magnesium $=0.206>$ sodium $=0.129>$ calcium $=0.081$, and in intact males, potassium $=0.499>$ phosphorus $=0.459>$ sodium $=0.105>$ magnesium $=0.024>$ calcium $=0.001)$. On the other hand, in females, the highest canonical weights were for potassium and calcium, whereas the lowest was for magnesium (potassium $=$ $0.539>$ calcium $=0.201>$ phosphorus $=0.178>$ sodium $=0.088>$ magnesium $=0.081$ ) The current results may help to understand the role of sex on strength and nature of the association among body protein, fat, and macrominerals in growing Saanen goats.
\end{abstract}

Key Words: dairy goat, multivariate analysis, sex, tissue composition

\section{Introduction}

The chemical composition of the body of an animal is the result of the influence of animal (e.g., sex, breed, and genetics), environment, management, and nutrition factors (Reid et al., 1955). Considering that protein, fat, and, macrominerals support the maintenance, growth, and production processes in animals (Lawrence et al., 2012), determining the magnitude of the interrelation among these body constituents in animals may be useful for optimizing nutrient utilization.

Recently, Teixeira et al. (2015) demonstrated that the quantities of mineral in the body of growing goats were linearly proportional to the amount of protein, exploring these relationships by a univariate approach. However, deposition

Received: November 7, 2017

Accepted: May 27, 2018

*Corresponding author: izabelle.teixeira@unesp.br

Copyright (c) 2018 Sociedade Brasileira de Zootecnia. This is an Open Access article distributed under the terms of the Creative Commons Attribution License (http://creativecommons.org/licenses/by/4.0/), which permits unrestricted use, distribution, and reproduction in any medium, provided the original work is properly cited. processes of protein, fat, and minerals in the body of animals are not independent (Reid et al., 1955). Therefore, the use of a multivariate approach may be appropriate for evaluating the interrelations among protein, fat, and macromineral deposition in the body of goats. In this regard, canonical correlation analysis may be suitable, because it measures the magnitude of interrelations between sets of multiple variables (Akbaş and Takma, 2005; Ventura et al., 2011).

In addition, Souza et al. (2017) demonstrated that male Saanen goats have greater body protein and lower body fat contents than females. Similarly, Vargas et al. (2017) reported that male Saanen goats have a greater body calcium, phosphorus, sodium, and magnesium contents than female Saanen goats. Hence, considering that sex affects body composition of Saanen goats, we hypothesize that the magnitudes of the interrelations among protein, fat, and macrominerals in the body of Saanen goats, may also be different between sexes. Thus, the objective of this study was to investigate the multivariate relationship among body protein, fat, and macrominerals in Saanen goats of different sexes (castrated males, females, and intact males) using canonical correlation analysis. 


\section{Material and Methods}

A dataset containing 274 individual records from four studies of protein body composition (Gomes, 2011; Almeida et al., 2015; Ferreira et al., 2015; Figueiredo et al., 2017) and from six studies of macromineral body composition (Ferreira, 2003; Figueiredo, 2011; Gomes et al., 2011; Soares, 2013; Santos Neto et al., 2016; Mendonça et al., 2017) of Saanen goats was developed. The studies were conducted in Jaboticabal, São Paulo, Brazil (21 ${ }^{\circ} 14^{\prime} 05^{\prime \prime} \mathrm{S}$, $48^{\circ} 17^{\prime} 09^{\prime \prime} \mathrm{W}$, and $595 \mathrm{~m}$ altitude).

This dataset was composed by body protein, fat, calcium, phosphorus, magnesium, sodium, and potassium contents of castrated male $(n=114)$, female $(n=69)$, and intact male $(\mathrm{n}=91)$ Saanen goats from 5 to $45 \mathrm{~kg}$ body weight (BW), expressed as total nutrient contents (grams) in the empty BW (EBW) (Table 1). Protein, fat, and macromineral contents of each animal in all experiments were calculated from the chemical composition in the body. Empty body samples were analyzed for the contents of crude protein $(\mathrm{CP}$; nitrogen analysis, performed via Dumas combustion using a LECO FP-528LC analyzer; LECO Corp., St. Joseph, MI; Etheridge et al., 1998) and fat (AOAC, 1990, method 930.15). Minerals were analyzed by performing a nitric perchloric acid wet digestion of

Table 1 - Descriptive statistics of major body constituents of male and female Saanen goats

\begin{tabular}{lcccc}
\hline & Mean & Minimum Maximum & SD \\
\hline Castrated males $(\mathrm{n}=114)$ & & & & \\
Protein $(\mathrm{g})$ & 3383 & 690 & 7618 & 1527 \\
Fat $(\mathrm{g})$ & 2974 & 35.0 & 12299 & 2524 \\
$\mathrm{Ca}(\mathrm{g})$ & 195.2 & 37.9 & 461.6 & 87.2 \\
$\mathrm{P}(\mathrm{g})$ & 148.9 & 26.6 & 330.4 & 61.8 \\
$\mathrm{Mg}(\mathrm{g})$ & 10.0 & 1.29 & 31.6 & 6.70 \\
$\mathrm{Na}(\mathrm{g})$ & 21.9 & 5.05 & 53.0 & 9.93 \\
$\mathrm{~K}(\mathrm{~g})$ & 28.9 & 5.62 & 97.8 & 18.0 \\
Females $(\mathrm{n}=69)$ & & & & \\
Protein $(\mathrm{g})$ & 3006 & 643 & 6322 & 1546 \\
Fat $(\mathrm{g})$ & 3622 & 85.7 & 14896 & 3681 \\
$\mathrm{Ca}(\mathrm{g})$ & 179.7 & 30.0 & 432.1 & 95.8 \\
$\mathrm{P}(\mathrm{g})$ & 127.7 & 26.9 & 267.2 & 58.8 \\
$\mathrm{Mg}(\mathrm{g})$ & 6.10 & 1.11 & 26.7 & 3.36 \\
$\mathrm{Na}(\mathrm{g})$ & 24.4 & 5.05 & 49.4 & 9.37 \\
$\mathrm{~K}(\mathrm{~g})$ & 29.1 & 5.85 & 79.3 & 17.0 \\
Intact males $(\mathrm{n}=91)$ & & & & \\
Protein $(\mathrm{g})$ & 2756 & 690 & 6977 & 1534 \\
Fat $(\mathrm{g})$ & 1912 & 65.5 & 9640 & 1928 \\
$\mathrm{Ca}(\mathrm{g})$ & 157.4 & 31.0 & 577.2 & 96.4 \\
$\mathrm{P}(\mathrm{g})$ & 119.8 & 26.6 & 317.1 & 62.5 \\
$\mathrm{Mg}(\mathrm{g})$ & 6.41 & 1.29 & 20.7 & 3.88 \\
$\mathrm{Na}(\mathrm{g})$ & 22.4 & 7.53 & 57.5 & 10.8 \\
$\mathrm{~K}(\mathrm{~g})$ & 26.4 & 5.62 & 86.1 & 17.0 \\
\hline & & & &
\end{tabular}

SD - standard deviation. samples (AOAC, 1990; method number 935.13), and body calcium, magnesium, sodium, and potassium contents were determined by atomic absorption (AOAC, 1990; method number 935.13). Body phosphorus contents were determined by colorimetry (AOAC, 1990; method number 965.17). All procedures used across studies were reviewed by the local Animal Care Committee (case no. 004972-09).

A canonical correlation analysis was performed using the CCA package (version 1.2-0) in $\mathrm{R}$ (version 3.3.1, R Foundation for Statistical Computing, Vienna, Austria) to explore the strength and nature of the association between organic and inorganic major constituents in the body of Saanen goats (Hair et al., 2014). Canonical correlation analysis is based on correlation between a linear combination of a set of variables (body protein and fat; $U_{\mathrm{i}}$ ) and a linear combination of another set of variables (body calcium, phosphorus, magnesium, sodium, and potassium; $\mathrm{V}_{\mathrm{i}}$ ). Thus, linear combinations of sets of variables can be defined as follows:

$$
\begin{gathered}
\mathrm{U}_{\mathrm{i}}=\mathrm{a}_{\mathrm{i} 1} \mathrm{Y}_{1}+\mathrm{a}_{\mathrm{i} 2} \mathrm{Y}_{2}+\ldots+\mathrm{a}_{\mathrm{ip}} \mathrm{Y}_{\mathrm{p}} \\
\mathrm{V}_{\mathrm{i}}=\mathrm{b}_{\mathrm{i} 1} \mathrm{X}_{1}+\mathrm{b}_{\mathrm{i} 2} \mathrm{X}_{2}+\ldots+\mathrm{b}_{\mathrm{iq}} \mathrm{X}_{\mathrm{q}},
\end{gathered}
$$

in which $\mathrm{a}_{\mathrm{ip}}$ and $\mathrm{b}_{\mathrm{iq}}$ are canonical weights, $\mathrm{p}$ and $\mathrm{q}$ are the number of variables of $\mathrm{U}_{\mathrm{i}}$ and $\mathrm{V}_{\mathrm{i}}$, and $\mathrm{U}_{\mathrm{i}}$ and $\mathrm{V}_{\mathrm{i}}$ are the $i$-th pair of canonical variates. The total number of pairs of canonical variates is defined by the minimum value between $p$ and $q . \mathrm{U}_{1}$ and $\mathrm{V}_{1}$ form the first pair of canonical variates, and $\mathrm{U}_{2}$ and $\mathrm{V}_{2}$ form the second pair of canonical variates. Therefore, first $\left(r_{1}\right)$ and second $\left(r_{2}\right)$ canonical correlations are defined as:

$$
\begin{aligned}
& r_{1}=\frac{\operatorname{Cov}\left(U_{1}, V_{1}\right)}{\sqrt{\operatorname{Var}\left(U_{1}\right) \operatorname{Var}\left(V_{1}\right)}} \\
& r_{2}=\frac{\operatorname{Cov}\left(U_{2}, V_{2}\right)}{\sqrt{\operatorname{Var}\left(U_{2}\right) \operatorname{Var}\left(V_{2}\right)}}
\end{aligned}
$$

Wilk's Lambda and Bartlett's tests were used to test significance of canonical correlations. In addition, redundancy index for each canonical correlation was determined to measure the amount of the dependent variable (protein and fat) variance accounted for the independent variables (calcium, phosphorus, magnesium, sodium, and potassium) (Hair et al., 2014).

\section{Results}

The analysis yielded, for each sex, two canonical correlations between $\mathrm{U}$ (i.e., body protein and fat) and $\mathrm{V}$ (i.e., body $\mathrm{Ca}, \mathrm{P}, \mathrm{Mg}, \mathrm{Na}$, and $\mathrm{K})$ canonical variates $(\mathrm{P}<0.01)$ (Table 2). The first and second canonical correlations 
were 0.962 and 0.554 , respectively, for castrated males; 0.973 and 0.593 , respectively, for females; and 0.977 and 0.604, respectively, for intact males (Figure 1). However, redundancy index (i.e., which represents the amount of variance in a dependent canonical variate explained by the independent canonical variate in the canonical correlation between $\mathrm{U}$ and $\mathrm{V}$ ) for first canonical correlations was $0.866,0.880$, and 0.898 , for castrated males, females, and intact males, respectively, whereas for the second canonical correlations, it was $0.019,0.025$, and 0.021 for castrated males, females, and intact males, respectively. Thus, first canonical correlations explained more than $87 \%$ of variance of the dependent variables, whereas the second canonical correlation explained lower than $0.025 \%$; then, only the first canonical correlation pairs were used in the analysis.
For canonical variate $\mathrm{U}_{1}$, canonical weights for protein were greater than that for fat, in castrated males (protein $=0.63$ $>$ fat $=0.41$ ), in females (protein $=0.96>$ fat $=0.039$ ), and in intact males (protein $=0.81>$ fat $=0.20)($ Table 2). For the canonical variate $\mathrm{V}_{1}$ in males, the highest canonical weights were for potassium and phosphorus, whereas the lowest were for calcium, in castrated males (potassium $=0.485>$ phosphorus $=0.259>$ magnesium $=0.206>$ sodium $=0.129$ $>$ calcium $=0.081)$ and in intact males (potassium $=0.499$ $>$ phosphorus $=0.459>$ sodium $=0.105>$ magnesium $=$ $0.024>$ calcium $=0.001)$. On the other hand, for females, the highest canonical weights were for potassium and calcium, whereas the lowest was for magnesium (potassium $=0.539>$ calcium $=0.201>$ phosphorus $=0.178>$ sodium $=0.088>$ magnesium $=0.081)($ Table 2$)$.

Table 2 - Standardized canonical coefficients of variates of canonical correlations analysis on major organic (protein and fat) and inorganic $(\mathrm{Ca}, \mathrm{P}, \mathrm{Mg}, \mathrm{Na}$, and $\mathrm{K}$ ) constituents in the body of Saanen goats of different sexes

\begin{tabular}{|c|c|c|c|c|c|c|}
\hline Sex & $\begin{array}{c}\text { Pair of } \\
\text { canonical variates }\end{array}$ & Standardized canonical variation combination ${ }^{1}$ & $\mathrm{R}_{\mathrm{c}}$ & $\mathrm{SR}_{\mathrm{c}}$ & RI & P-value \\
\hline \multirow{2}{*}{ Castrated males } & $\begin{array}{c}\text { First set of canonical } \\
\text { variates }\end{array}$ & $\begin{array}{l}\mathrm{U}_{1}=0.626 \times \text { Protein }+0.405 \times \text { Fat } \\
\mathrm{V}_{1}=0.081 \times \mathrm{Ca}+0.259 \times \mathrm{P}+0.206 \times \mathrm{Mg}+0.129 \times \mathrm{Na}+0.485 \times \mathrm{K}\end{array}$ & 0.962 & 0.926 & 0.866 & $<0.01$ \\
\hline & $\begin{array}{l}\text { Second set of } \\
\text { canonical variates }\end{array}$ & $\begin{array}{l}\mathrm{U}_{2}=1.976 \times \text { Protein }-2.033 \times \text { Fat } \\
\mathrm{V}_{2}=0.206 \times \mathrm{Ca}+0.576 \times \mathrm{P}+0.521 \times \mathrm{Mg}-0.533 \times \mathrm{Na}-0.649 \times \mathrm{K}\end{array}$ & 0.554 & 0.307 & 0.020 & $<0.01$ \\
\hline \multirow{2}{*}{ Females } & $\begin{array}{l}\text { First set of canonical } \\
\text { variates }\end{array}$ & $\begin{array}{l}\mathrm{U}_{1}=0.964 \times \text { Protein }+0.039 \times \text { Fat } \\
\mathrm{V}_{1}=0.201 \times \mathrm{Ca}+0.178 \times \mathrm{P}+0.081 \times \mathrm{Mg}+0.088 \times \mathrm{Na}+0.539 \times \mathrm{K}\end{array}$ & 0.973 & 0.947 & 0.880 & $<0.01$ \\
\hline & $\begin{array}{l}\text { Second set of } \\
\text { canonical variates }\end{array}$ & $\begin{array}{l}\mathrm{U}_{2}=2.380 \times \text { Protein }-2.568 \times \text { Fat } \\
\mathrm{V}_{2}=0.470 \times \mathrm{Ca}+1.514 \times \mathrm{P}-0.769 \times \mathrm{Mg}-0.424 \times \mathrm{Na}-0.768 \times \mathrm{K}\end{array}$ & 0.593 & 0.351 & 0.025 & $<0.01$ \\
\hline \multirow{2}{*}{ Intact males } & $\begin{array}{l}\text { First set of canonical } \\
\text { variates }\end{array}$ & $\begin{array}{l}\mathrm{U}_{1}=0.814 \times \text { Protein }+0.201 \times \text { Fat } \\
\mathrm{V}_{1}=0.001 \times \mathrm{Ca}+0.459 \times \mathrm{P}+0.024 \times \mathrm{Mg}+0.105 \times \mathrm{Na}+0.499 \times \mathrm{K}\end{array}$ & 0.977 & 0.954 & 0.898 & $<0.01$ \\
\hline & $\begin{array}{l}\text { Second set of } \\
\text { canonical variates }\end{array}$ & $\begin{array}{l}\mathrm{U}_{2}=2.309 \times \text { Protein }-2.440 \times \text { Fat } \\
\mathrm{V}_{2}=0.002 \times \mathrm{Ca}+2.062 \times \mathrm{P}-0.389 \times \mathrm{Mg}-0.009 \times \mathrm{Na}-1.722 \times \mathrm{K}\end{array}$ & 0.604 & 0.365 & 0.021 & $<0.01$ \\
\hline
\end{tabular}

$\mathrm{R}_{\mathrm{c}}$ - canonical correlation; $\mathrm{SR}_{\mathrm{c}}$ - squared canonical correlation; $\mathrm{RI}$ - redundancy index: proportion of variance of the dependent canonical variate accounted by the independent canonical variate.

${ }^{1}$ Protein, fat, $\mathrm{Ca}, \mathrm{P}, \mathrm{Mg}, \mathrm{Na}$, and $\mathrm{K}$, are the nutrient contents $(\mathrm{g})$ in the body of castrated male, female, and intact male Saanen goats.
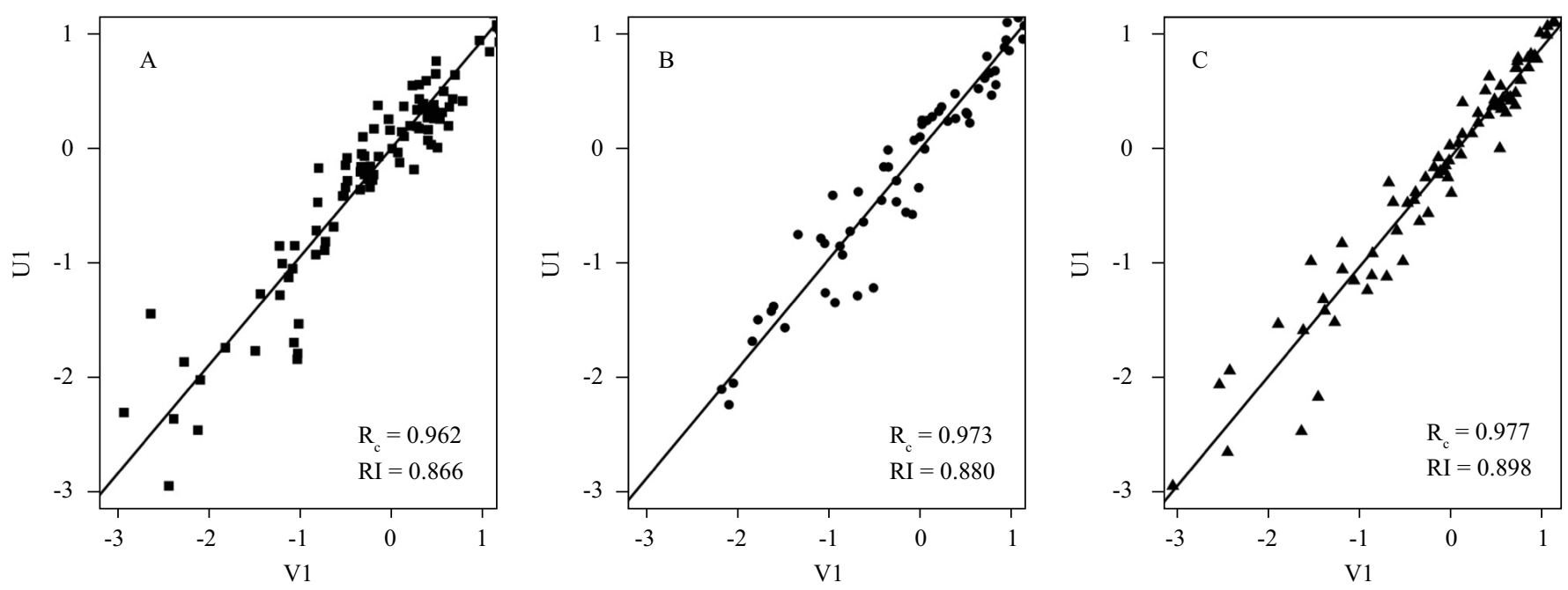

$\mathrm{R}_{\mathrm{c}}$ - canonical correlation; $\mathrm{RI}$ - redundancy index.

All canonical correlations were significant at $\mathrm{P}<0.01$.

Figure 1 - Canonical correlation scores of the first canonical variates of canonical correlations analysis on major organic (protein and fat; U1) and inorganic ( $\mathrm{Ca}, \mathrm{P}, \mathrm{Mg}, \mathrm{Na}$, and $\mathrm{K} ; \mathrm{V1})$ constituents in the body of castrated male ( $\mathbf{-} ; \mathrm{A})$, female $(\bullet$; B), and intact male $(\boldsymbol{\Delta} ; \mathrm{C})$ Saanen goats. 


\section{Discussion}

The objective of the current study was to investigate the relationship among major body constituents in male and female Saanen goats. Our results suggested that body phosphorus and potassium were the principal macrominerals affecting body protein in male Saanen goats, whereas body potassium and calcium were the main minerals affecting body protein in females.

Deposition processes of major organic and inorganic body constituents of an animal are not independent (Reid et al., 1955). This is in accordance with the results of the present study, which revealed high and significant canonical correlations between major organic (protein and fat) and inorganic (calcium, phosphorus, magnesium, sodium, and potassium) constituents. Likewise, over $87 \%$ of variance of major organic constituents was explained by major inorganic constituents in the body of Saanen goats (Table 2). Therefore, the relationship among protein, fat, and macrominerals in the body of goats should be analyzed using multivariate data analysis techniques, in which canonical correlation analysis may be suitable.

Sex influences body composition, in which hormonal regulation establishes biological limits for protein and fat deposition and defines differences in body composition between sexes (Byers, 1982). Our results revealed that protein and fat contributed in approximately 60 and $40 \%$, 96 and 4\%, 80 and $20 \%$, in castrate males, females, and intact males, respectively, to the first canonical variate $\mathrm{U}_{1}$ (Table 2). Thus, irrespective of sex, body protein has greater contribution than fat to major organic constituents. This is in accordance with Webster (1986) and Lawrence et al. (2012), who suggested that deposition of fat in ruminants is delayed in relation to body protein, increasing fat deposition rate when deposition of water, protein, and minerals is in a descending phase.

Moreover, the contributions of protein and fat to total major constituents were different between sexes. This is in accordance with Almeida et al. (2016) and Souza et al. (2017), who demonstrated that protein and fat deposition patterns are different between sexes in growing Saanen goats. Hence, we can conclude that sex not only affects body protein and fat contents in Saanen goats, but it also influences the relationship between protein and fat accretion in the body. Sex effects on the interrelation between body protein and fat using a multivariate approach had not been assessed until now in goats, and the results of this study may help to understand the role of sex on the interrelation between protein and fat deposition processes in this species.
Similar to protein and fat, sex modulates mineral dynamics and, in consequence, the mineral deposition in the body of animals (Cannata et al., 2010). Our data revealed that castrated males (potassium $>$ phosphorus $>$ magnesium $>$ sodium $>$ calcium), intact males (potassium $>$ phosphorus $>$ sodium $>$ magnesium $>$ calcium), and females (potassium $>$ calcium $>$ phosphorus $>$ sodium $>$ magnesium) have different macromineral orders of contribution to total major inorganic constituents (Table 2). This is in accordance with previous studies which suggested that testosterone levels are different between sexes (Lawrence et al., 2012). Testosterone regulates GH activity, which modulates calcium and phosphorus dynamics in the body (Breier, 1999; Bouillon et al., 2003). Similarly, studies with rats (Schrier, 2006; Squires, 2010) suggested that intact males have greater level of aldosterone, a hormone that regulates sodium and potassium dynamics in the body (Suttle, 2010), than females. Therefore, the differences between sexes in macromineral orders of contribution to total major inorganic constituents may suggest that metabolic processes associated with mineral deposition could be different between sexes. This information may help to explain why sex affects macromineral body deposition in Saanen goats (Vargas et al., 2017). Also, it may be useful for future studies aiming to understand the role of sex on biochemical mechanisms involved in mineral deposition in goats.

From the inspection of canonical weights of $U$ and $\mathrm{V}$ variates (Table 2), it was observed that, irrespective of sex, U canonical variate was mainly defined by protein, and $\mathrm{V}$ canonical variates in males (castrated and intact males) were mainly defined by phosphorus and potassium. Then, body phosphorus and potassium were the principal macrominerals affecting body protein in male Saanen goats (Figures 2A and C). These results make biological sense, considering that male Saanen goats have greater protein contents than females (Souza et al., 2017). Phosphorus plays a role in metabolic functions of ruminants, including energy utilization and transfer via AMP, ADP, and ATP, with implications in amino acid and protein synthesis (Suttle, 2010). Similarly, potassium participates actively in the synthesis of protein by amino acids and contributes to the regulation and activity of the sodium/potassium ion pump, a process that drives amino acid and glucose transport into the cells (Suhail, 2010). Therefore, considering the link among phosphorus, potassium, and protein metabolism, it is expected that, in males, an increase in deposition of $\mathrm{P}$ and $\mathrm{K}$ will have a greater impact on body protein.

In the case of females, $\mathrm{V}$ canonical variate was mainly defined by body potassium and calcium. In this case, body 
A



B



$\mathrm{C}$



Values in the parenthesis refer to standardized canonical coefficients; values next to arrows correspond to body macromineral contributions (expressed as standardized canonical coefficient/sum of standardized canonical coefficients of all body macrominerals evaluated $\times 100$ ) to body protein accretion.

Figure 2 - Contributions of macromineral body composition to body protein accretion of castrated male (A), female (B), and intact male (C) Saanen goats.

potassium and calcium were the main minerals affecting body protein in female Saanen goats (Figure 2B). This may be because females have greater body potassium and calcium than males (Vargas et al., 2017) and because potassium and calcium are metabolically interrelated in the animal body (Lemann et al., 1993). Potassium exerts a beneficial effect on the skeleton through anion provided by potassium salts and an anion-independent effect of potassium on calcium excretion and bone metabolism (Bushinsky et al., 1997; Zhu et al., 2009). Therefore, considering the link between muscle and bone metabolism in the body of ruminants (Geay, 1984; Lawrence et al., 2012) and the greater body potassium and calcium in females, it is expected that, in females, an increase in body potassium and calcium will have a greater impact on body protein.

As minerals and protein accretion in the body reach a plateau while fat accretion can continue (Lawrence et al., 2012), it is possible that, for heavier goats (i.e., BW greater than $45 \mathrm{~kg}$ ), the amount of fat in the body, especially for females, will be greater than the values observed in our study. Therefore, we highlight that goats with BW out of the range we used in this study may show different relationships of body constituents.

Based on the aforementioned, the magnitude of interrelations among protein, fat, and macromineral are different between male (castrated and intact males) and female Saanen goats from 5 to $45 \mathrm{~kg}$ BW. Elucidation of differences between sexes with regards to interrelations of major body constituents in goats may be useful to understand the role of sex on metabolic links among body protein, fat, and macrominerals in this species. The findings of this study may help to design diets with adequate nutrient contents for growing goats. Also, they may contribute for designing additional studies to a better understanding of the interrelations between organic and inorganic body constituents and the factors that may affect them in ruminants.

\section{Conclusions}

The hypothesis that the magnitudes of the interrelations among protein, fat, and macrominerals in the body of Saanen goats differ between sexes is not rejected. This study suggests that potassium and phosphorus are the main macrominerals affecting body protein of male Saanen goats, whereas in females, body potassium and calcium are the main minerals affecting body protein.

\section{Acknowledgments}

The authors are thankful to the Fundação de Amparo à Pesquisa do Estado de São Paulo (FAPESP; grant number 2014/14734-9) and Asociación Universitaria Iberoamericana de Postgrado (AUIP, Grant number 166754-1), for the financial support.

\section{References}

Akbaş, Y. and Takma, Ç. 2005. Canonical correlation analysis for studying the relationship between egg production traits and body weight, egg weight and age at sexual maturity in layers. Czechoslov. Journal of Animal Science 50:163-168. https://doi.org/10.17221/4010-CJAS 
Almeida, A. K.; Resende, K. T.; Silva, S. P.; Soares, D. C.; Fernandes, M. H. M. R. and Teixeira, I. A. M. A. 2015. Protein requirements in male and female Saanen goats. Revista Brasileira de Zootecnia 44:397-404. https://doi.org/10.1590/S1806-92902015001100004

Almeida, A. K.; Resende, K. T.; Tedeschi, L. O.; Fernandes, M. H. M. R.; Regadas Filho, J. G. L. and Teixeira, I. A. M. A. 2016. Using body composition to determine weight at maturity of male and female Saanen goats. Journal of Animal Science 94:2564-2571. https://doi.org/10.2527/jas.2015-0060

AOAC - Association of Official Analytical Chemistry. 1990. Official methods of analysis. 15th ed. AOAC International, Arlington, VA.

Bouillon, R.; Van Cromphaut, S. and Carmeliet, G. 2003. Intestinal calcium absorption: molecular vitamin D mediated mechanisms. Journal of Cellular Biochemistry 88:332-339. https://doi.org/10.1002/jcb.10360

Breier, B. H. 1999. Regulation of protein and energy metabolism by the somatotropic axis. Domestic Animal Endocrinology 17:209-218. https://doi.org/10.1016/S0739-7240(99)00038-7

Bushinsky, D. A.; Riordon, D. R.; Chan, J. S. and Krieger, N. S. 1997. Decreased potassium stimulates bone resorption. American Journal of Physiology 272:F774-F780. https://doi.org/10.1152/ ajprenal.1997.272.6.F774

Byers, F. M. 1982. Nutritional factors affecting growth of muscle and adipose tissue in ruminants. Federation Proceedings 41:2562-2566.

Cannata, D.; Vijayakumar, A.; Fierz, Y. and LeRoith, D. 2010. The GH/ IGF-1 axis in growth and development: New insights derived from animal models. Advances in Pediatrics 57:331-351. https://doi.org/10.1016/j.yapd.2010.09.003

Etheridge, R. D.; Pesti, G. M. and Foster, E. H. 1998. A comparison of nitrogen values obtained utilizing the Kjeldahl nitrogen and Dumas combustion methodologies (Leco CNS 2000) on samples typical of an animal nutrition analytical laboratory. Animal Feed Science and Technology 73:21-28. https://doi.org/10.1016/S0377-8401(98)00136-9

Ferreira, A. C. D. 2003. Composição corporal e exigências nutricionais em proteína, energia e macrominerais de caprinos Saanen em crescimento. Tese (D.Sc.). Universidade Estadual Paulista, Jaboticabal, São Paulo.

Ferreira, A. C. D.; Yáñez, E. A.; Medeiros, A. N.; Resende, K. T.; Pereira Filho, J. M.; Fernandes, M. H. M. R.; Almeida, A. K. and Teixeira, I. A. M. A. 2015. Protein and energy requirements of castrated male Saanen goats. Small Ruminant Research 123:8894. https://doi.org/10.1016/j.smallrumres.2014.10.017

Figueiredo, F. O. M. 2011. Exigências nutricionais de cabritas Saanen em crescimento dos 30 aos $45 \mathrm{~kg}$. Dissertação (M.Sc.). Universidade Estadual Paulista, Jaboticabal, São Paulo.

Figueiredo, F. O. M.; Leite, R. F.; St-Pierre, N. R.; Resende, K. T.; Almeida, A. K.; Souza, A. P. and Teixeira, I. A. M. A. 2017. Energy and protein requirements of weaned male and female Saanen goats. Journal of Animal Physiology and Animal Nutrition 101:1014-1025. https://doi.org/10.1111/jpn.12539

Geay, Y. 1984. Energy and protein utilization in growing cattle. Journal of Animal Science 58:766-778. https://doi.org/10.2527/jas1984.583766x

Gomes, H. F. B. 2011. Composição corporal e exigências nutricionais de caprinos Saanen machos dos 30 aos $45 \mathrm{~kg}$. Tese (D.Sc.). Universidade Estadual Paulista, Jaboticabal, São Paulo.

Gomes, R. A.; Oliveira-Pascoa, D.; Teixeira, I. A. M. A.; Medeiros, A. N.; Resende, K. T.; Yáñez, E. A. and Ferreira, A. C. D. 2011. Macromineral requirements for growing Saanen goat kids. Small Ruminant Research 99:160-165. https://doi.org/10.1016/j.smallrumres.2011.04.012
Hair, J. F.; Black, W. C.; Babin, B. J. and Anderson, R. E. 2014 Multivatiate data analysis. 7th ed. Pearson, Edinburg, UK.

Lawrence, T.; Fowler, V. and Novakofski, J. 2012. Growth of farm animals. 3rd ed. CAB International Publishing House, Oxfordshire, UK.

Lemann, J., Jr.; Pleuss, J. A. and Gray, R. W. 1993. Potassium causes calcium retention in healthy adults. Journal of Nutrition 123:16231626. https://doi.org/10.1093/jn/123.9.1623

Mendonça, A. N.; Härter, C. J.; Souza, S. F.; Oliveira, D.; Boaventura Neto, O.; Biagioli, B.; Resende, K. T. and Teixeira, I. A. M. A. 2017. Net mineral requirements for growth of Saanen goat kids in early life are similar among genders. Journal of Animal Physiology and Animal Nutrition 101:113-120. https://doi.org/10.1111/jpn.12518

Reid, J. T.; Wellington, G. H. and Dunn, H. O. 1955. Some relationships among the major chemical components of the bovine body and their application to nutritional investigations. Journal of Dairy Science 38:1344-1359. https://doi.org/10.3168/jds.S0022-0302(55)95117-1

Santos Neto, J. M.; Resende, K. T.; Teixeira, I. A. M. A.; Vargas, J. A. C.; Lima, A. R. C.; Leite, R. F.; Figueiredo, F. O. M.; Tedeschi, L. O. and Fernandes, M. H. M. R. 2016. Net macromineral requirements in male and female Saanen goats. Journal of Animal Science 94:3409-3419. https://doi.org/10.2527/jas.2016-0350

Schrier, R. W. 2006. Water and sodium retention in edematous disorders: Role of vasopressin and aldosterone. American Journal of Medicine 119:S47-53. https://doi.org/10.1016/j.amjmed.2006.05.007

Soares, D. C. 2013. Exigências de macrominerais em caprinos Saanen de diferentes sexos na fase final de crescimento. Dissertação (M.Sc.). Universidade Estadual Paulista, Jaboticabal, São Paulo.

Souza, A. P.; St-Pierre N. R.; Fernandes, M. H. M. R.; Almeida, A. K.; Vargas, J. A. C.; Resende, K. T. and Teixeira, I. A. M. A. 2017. Sex effects on net protein and energy requirements for growth of Saanen goats. Journal of Dairy Science 100:4574-4586. https://doi.org/10.3168/jds.2016-11895

Squires, E. J. 2010. Applied animal endocrinology. CABI, Wallingford, UK.

Suhail, M. 2010. $\mathrm{Na}^{+}, \mathrm{K}^{+}$-ATPase: Ubiquitous multifunctional transmembrane protein and its relevance to various pathophysiological conditions. Journal of Clinical and Medicine Research 2(1):1-17. https://doi.org/10.4021/jocmr2010.02.263w

Suttle, N. F. 2010. Mineral nutrition of livestock. 4th ed. CABI International, Wallingford, UK.

Teixeira, I. A. M. A.; Härter, C. J.; Pereira Filho, J. M.; Silva Sobrinho, A. G. and Resende K. T. 2015. Mineral requirements for growth and maintenance of F1 Boer $\times$ Saanen male kids. Journal of Animal Science 93:2349-2356. https://doi.org/10.2527/jas.2014-8588

Vargas, J. A. C.; Almeida, A. K.; Souza, A. P.; Fernandes, M. H. R. M.; Resende, K. T. and Teixeira, I. A. M. A. 2017. Sex effects on macromineral requirements for growth in Saanen goats: a meta-analysis. Journal of Animal Science 95:4646-4657. https://doi.org/10.2527/jas2017.1825

Ventura, H. T.; Lopes, P. S.; Peloso, J. V.; Guimarães, S. E. F.; Carneiro, A. P. S. and Carneiro, P. L. S. 2011. A canonical correlation analysis of the association between carcass and ham traits in pigs used to produce dry-cured ham. Genetics and Molecular Biology 34:451-455. https://doi.org/10.1590/S1415-47572011000300014

Webster, A. J. F. 1986. Factors affecting the body composition of growing and adult animals. Proceedings of the Nutrition Society 45:45-53. https://doi.org/10.1079/PNS19860034

Zhu, K.; Devine, A. and Prince, R. L. 2009. The effects of high potassium consumption on bone mineral density in a prospective cohort study of elderly postmenopausal women. Osteoporosis International 20:335-340. https://doi.org/10.1007/s00198-008-0666-3 